\title{
PROPOSED STATE AND LOCAL STATUTES IMPOSING PUBLIC LIABILITY IN TORT .
}

\author{
EDWIN BORCHARD*
}

I

Some twenty years have now elapsed since the agitation for community assumption of liability in tort began to receive general attention and public approval. Since that time numerous statutes have been passed dealing with the subject by piecemeal. There is no uniformity in the development throughout the states and cities of this country, but even where the reform is not yet reflected in actual statutes, judicial opinion has tended to question the ancient maxims which left the victim of a community injury without practical redress. The movement for reform in the distribution of the risks of injury has culminated in the revised federal tort claims bill which on January $14,1942,{ }^{1}$ received the strong endorsement and recommendation of President Roosevelt. ${ }^{2}$

The anachronisms and injustices produced by the theories of sovereign immunity from suit and sovereign exemption from tort liability have been adequately discussed. ${ }^{3}$ The present issue is therefore no longer one of proving the impropriety of old rules which purported to discharge a societal obligation by throwing liability on a negligent but often financially irresponsible officer or body, but of distributing effectively and justly the costs of official maladministration due to the inevitable consequences of human deficiencies in the operation of the governmental machine. On the one hand, it is now recognized as unfair to allow the unfortunate victim of official negligence to sustain alone the burden of his loss; on the other hand, it is poor

* LL.B., I905, New York Law School; A.B., 1908, Ph.D., 1913, Columbia University. Professor of Law, Yale School of Law, since rgi7. Author: Neutrality for THE UNITEd States (with P. S. Lage) (I940); Convicting the Innocent (I932); Latin-American Commercinl Law (with T. Esquivel Obregón) (1920); Declaratory JUdGMenTs (1918, I934, rev. ed. 1941); and other books. Contributor to American and European legal periodicals.

188 Cong. Rec. Jan. I4, 1942, at 323. See Armstrong and Cockrill, The Federal Torts Claim Bill, infra p. 327.

2 The first federal bill was introduced by Representative Underhill of Massachusetts in 1925, and the current bill, S. 2221, 77th Cong., 2nd Sess., introduced by Senator Van Nuys Jan. 23, 1942, carrics over the fundamental principles of the $x 925$ bill. In 1928 that bill, as amended, was passed by House and Senate, but was pocket-vetoed by President Coolidge because the Comptroller General had worked his way into the bill as the administrative judge of tort claims against the United States, and then was to be counsel for the United States on appeals from his decisions to the Court of Claims. This met with objection from the Attorney General. Then for some years the Employees' Compensation Commission sought to enlarge its jurisdiction in the revised bill of Senator Howell in the early '30's. Finally, Attorncy General Cummings, appreciating the need for this legislation, made the bill an administration mcasure and it has so remained.

${ }^{3} \mathrm{Cf}$. in lieu of more voluminous citations Borchard, State and Municipal Liability in Tort-Proposed Statutory Reform (1934) 20 A. B. A. J. 747-752, 793-794, and literature there cited. 
administration to purport to make the officer alone responsible. Foreign systems had long reached the conclusion that the employing governmental unit should stand behind its erring official and assume responsibility for the community as a whole for certain types of flagrant defects in administration.

This has led some reformers, influenced by the theory of workmen's compensation and other instances of community assumption of risk, to advocate a theory of social insurance, without fault. The country, however, is not prepared for such a radical institutional change. Since legislatures must be convinced, it is best to adhere to common law conceptions of fault and simply transfer to the community the responsibility for some of the major delinquencies, tested by common law principles, in the administration of the governmental machine. This does not mean that the government shall be an insurer or that every activity which may produce injury to an individual shall be the source of governmental responsibility. The government is not in the same position as a private corporation and may properly be afforded certain exceptions and defenses which would not be available to a private corporation. I am not among those who frown upon the distinction between "corporate" and "governmental" activities, since this division of public function has an historical origin going back to Bartolus, and but for this distinction we might have had even more difficulty in making inroads upon the much misunderstood and surely undemocratic maxim that the king, state or government can do no wrong. The distinction, indeed, has served a valuable purpose, first, in segregating for community liability at least a large class of municipal activity, and second, after long exploitation of the distinction, to expose its artificiality and frequent injustice.

Two activities effectively demonstrated the practical impropriety of continuing the distinction in modern life-first, the legislative expansion of liability for the defective care and maintenance of highways, streets and sidewalks, essentially governmental functions, and second, the legislative admission that injuries inflicted through the negligent operation of publicly-owned or operated motor vehicles should impose liability regardless of whether the vehicle was employed by a municipal transportation system, public suppliers of gas or electricity, a garbage collector, a policeman or a fireman. Furthermore, the considerable increase in the ownership of public property made it seem inappropriate to claim exemption from the rules governing negligence and nuisance.

But even if we have now reached the stage where.substantive community responsibility with certain exceptions is conceded, we are still far from agreement on the statutory expression of such liability and the procedural conditions on which it may be practically administered. Apart from orderly procedure, the community needs protection against the unfair and dishonest claimant and may well demand from the legislature statutory safeguards against imposition. With this qualification, there has been much legislative activity during the last few years in recognition of the change in public and social opinion which now accepts community responsibility in tort. Some states, like New York and California, have made great advances which might 
serve as a model. In some cities, like Chicago, an enlightened effort has been made to administer more effecively and justly the limited liability admitted. The admission of liability for state activity is of comparatively recent date, and here New York, Michigan and Illinois appear to be in the vanguard. During the last ten years committees of the American Bar Association and of the American Political Science Association, of which the writer has had the honor to be chairman, have studied the subject with a view to sound statutory change. The Committee on Public Administration of the Social Science Research Council has sponsored exhaustive investigations of the administration of municipal tort liability in the cities of Los Angeles, Boston, Chicago, Medford, Massachusetts, and Austin, Texas. This experience is now available.

\section{Statutes}

As already observed, the crucial problem now is to frame the substantive law and the procedural requirements in such a way as to do justice to the individual and protect the community against imposition. The financial consequences of the acceptance of community tort liability are to some extent known and yet to some degree unknown. The studies made in the five cities above mentioned indicate that possibly five sixths of community tort liability is already covered by the statutes or judicial law which admit municipal liability in the field of "corporate" activity, in the care of streets and sidewalks, in the management of public buildings, and in the operation of municipally-owned or commandeered vehicles. It is established by these studies that the bulk of the claims are small, that most of them are either settled or withdrawn, and that of those which go to judicial recourse, only a relatively small percentage, if any, of the total claim is recovered. The gaps to be filled by an extension of tort liability would involve mainly what has been known as governmental activity, namely, police and fire administration, recreation and public education, public health and hospitalization, transportation facilities like airports, and similar public services. The experience in these fields would probably not be greatly different from those already covered. The unknown factor in the equation is the possibility of some sudden catastrophe, like the breaking of the St. Francis Dam in Los Angeles, which flooded and damaged a large valley area and imposed a community loss which had to be covered by a bond issue, to be liquidated over a long period. These occurrences are rare and their attribution to the negligence of a public officer even rarer.

Other problems present themselves. Should there be separate Acts for the administration of state liability through a state board or court, and for municipal liability to be administered by the city alone on its own responsibility? Is it feasible to include both state and political subdivision in one statute to be administered under the supervision of a central state administrative board, with the state assuming some of the liability of the small towns beyond a certain amount? This is a very practical problem, since the small towns by habit and experience are likely to vote through their representatives against the assumption of community liability if they themselves are 
to bear more than a limited amount. They may feel that one negligent accident, especially to a stranger, might swamp them financially. In the drafts to be presented hereafter an effort has been made to present model alternatives by way of (a) state liability alone, (b) municipal liability alone, and (c) a limited joint assumption of the liability.

Further questions present themselves: (a) Shall the statutes, with a view to insuring legislative support, admit liability for certain specific matters only, admitting of piecemeal extension as experience dictates, or (b) shall the statutes admit community tort liability in principle with certain stated exceptions only, as in the case of the federal bill? Expert support can be obtained for either solution.

If exceptions are to be made, what should they cover? The federal bill, after excluding discretionary functions from the category of tort, excepts claims for loss, miscarriage or negligent transmission of postal matter, claims in connection with the assessment or collection of taxes or customs duties, or detention of goods by customs officers, claims arising out of the administration of the Trading with the Enemy Act or by the establishment of a quarantine, injuries to vessels going through the Panama Canal, claims arising out of assault, battery, false imprisonment, false arrest, malicious prosecution, abuse of process, libel, slander, misrepresentation, deceit or interference with contract rights-breach of contract, express or implied, being already covered by the Tucker Act of 1887 -damages caused by the fiscal operations of the Treasury, claims arising out of the activities of the military or naval forces or coast guard during time of war. These exceptions are comprehensible. While some of them would make a city liable, the question remains whether some similar exceptions should not be made in a municipal liability bill positing tort liability in principle.

Shall a jury be permitted? In the administration of federal and state liability, whether through administrative channel or courts, juries are excluded. In the matter of municipal liability, corporation counsel from New York and Chicago regard the jury as a protection against a possibly weak judge and see no danger of exaggerated verdicts because the government is a defendant. Plaintiffs, however, generally demand juries, which might indicate a belief that they are an advantage to the claimant. The drafts submitted allow cities to exercise an option in demanding jury trial.

Negligence. There is some expert opinion demanding a definition of the standard known as negligence or lack of due care. Definition is difficult because negligence depends so greatly upon the state of facts to which the standard is to be applied. California holds that running motor vehicles are free from negligence in cases of emergency provided an audible signal was given by siren. But it is difficult to define emergency. Excessive speed may be required in going to a fire but not in returning, so that the standard of negligence would here be different. Mr. David of Los Angeles, an exceptionally qualified expert, believes that in some cases the city might be more liable than a private owner, for example, in the case of falling limbs from trees on unimproved land devoted to park uses, although negligence here might be difficult to demonstrate. Whereas liability for defective drains and surface water deposits is now 
about the same in Los Angeles as private liability, Mr. David fears that a general statute might result in imposing more liability on the city than on private individuals. He believes that the public is ready to assume some liability not based on fault, as in the case of the stray bullet of the policeman, the damage to parked automobiles from passing fire apparatus, etc., unless the victim is guilty of contributory negligence. Perhaps belief in an emergency, such as a false fire alarm, should be enough, without proof of the actual existence of such emergency. There is not much sentiment for limiting. contributory negligence to comparative negligence as in admiralty, so that even slight contributory negligence would defeat a claim.

Pain and suffering. The Boston experience has led the Boston investigators ${ }^{4}$ to recommend that this element of liability in personal injury cases be eliminated. This is justified on the ground that pain is an unknown and precarious element in damages and that its exclusion would protect the city against exaggerated claims. While everyone would protect the city against excessive claims, not all experts agree that pain and suffering should be excluded as an element of damage. Perhaps if the jury were eliminated it would be unnecessary to exclude it.

\section{Procedural Limitations}

It is obvious that there must be some safeguards not only against unjust or unsubstantial claims, but against late claims filed so tardily that the defendant municipality has no opportunity to examine the place of injury, the person injured, the witnesses and the attending facts. For this reason a fairly prompt notice of the claim is necessary whether prosecution of the claim follow or not. Some cities require notice of the claim within thirty days, and Massachusetts limits notice in snow and ice cases to ten days. There is a feeling that the thirty-day period might be extended by court or city attorney if the disability of the victim is such as to prevent timely notice.

Since the statutory notice is the condition of a valid claim, it is important whether the conditions be applied strictly or loosely. The California and some other courts hold that a defective notice may be valid if the defect is such as not to have prejudiced the city. But there is no waiver of the requirement that the notice must be filed in the statutory period. Massachusetts holds that a defective notice must be corrected within five days if the city notifies the claimant of the defect. The thirty-day provision appeals to some courts as so short as to persuade them to adopt a doctrine of substantial compliance with the notice requirements. For that reason, the Chicago expert favors a ninety-day notice rather than thirty, since Chicago obtains cooperation from other government departments in reporting and investigating claims. Nevertheless, it appears that $60 \%$ of the cases in Chicago are blind, that is, without report from the police. Such a report is likely in motor vehicle accidents but not necessarily in street and sidewalk accidents.

Until persons become familiar with the new law in cities not now admitting wide liability, it might be appropriate to construe the notice requirements broadly, whereas in municipalities in which claims are common it may be more appropriate to con-

\footnotetext{
-Messrs. Edgar Fuller and A. James Casner.
} 
strue the requirements strictly. Notice may also be less important where the claim may be submitted, as in Chicago, by petition to the City Council without opportunity for judicial relief.

There is some difference of opinion among the experts as to whether a complete claim form, as in Los Angeles, should be filled out by the claimant and filed under oath. There is some advantage in a claim form, since it assists the claimant in specifying the details of his claim and affords the city some protection, by opportunity for investigation, against unfounded claims. Since the city's protection does lie in a speedy investigation whenever the police or other department reports an injury, it may be well to insist on claimant cooperation in making the necessary investigation. This includes speed in filing the notice of claim.

It should not matter whether the claimant or next friend signs the notice of claim, nor is it essential that the notice be under oath. In case of suit of course a verified complaint must be filed. The claimant should also, as in New York, be compelled to submit to examination before trial, including a medical examination. This is accomplished in Chicago by making examination a condition of settlement, which in Chicago is permissible only after suit has been filed. In New York a claimant for judicial relief must show that he has filed the claim, submitted to an examination, and that the Comptroller, an independent accounting officer, has failed to pay it.

Settlement. There should be an opportunity to settle meritorious claims before suit and trial, but there is considerable difference of opinion as to who should assume responsibility for such settlement. It seems to be a fact that even in cases where the City Council reserves the final power to settle claims, it relies largely on the city attorney's office to make the necessary recommendation. Some cities, like Philadelphia and Medford, appropriate a sum of money to the city attorney for the settlement of claims, throwing responsibility upon him for safeguarding the interests of the city. In New York, the Comptroller decides on the payment of claims, the Law Department coming into the case only after the Comptroller rejects the claim. There is an opinion that since in small cities the law officer has no facilities for making the necessary investigations, the City Council, which presumably also has little opportunity of that kind, should assume responsibility for the settlement. In large cities, where the Law Department is likely to be well equipped, it would be feasible to allow the city attorney to settle claims subject to the approval of more than one official of the Department, and perhaps subject to the approval of the City Council. It has been said that to allow a law department to pass upon claims presupposes a budget, and since only a small percentage of cities have budgets, the Council must necessarily act. Perhaps the city attorney should have authority finally to settle only small claims, at any stage of the proceedings, whereas large claims should be settled by the Council upon advice and recommendation of the city attorney, but under Council responsibility. This is the Los Angeles practice.

Most claims are small, and hardly warrant the expense of a judicial trial. Hence the city attorney ought to consider himself a quasi-judicial officer, acting as much in 
the interests of the citizen as in the interests of the community. In either event, city attorney or Council, the first responsibility for investigation and judging the merits of the claim will necessarily fall on the city attorney, who in the case of small claims would make or offer a final settlement and in the large claims would recommend. But in either event his determination would carry much weight. The Assistant Corporation Counsel in Chicago, in charge of tort claims, favors the power of the office to settle claims up to $\$ 7,500$, or even $\$ 10,000$.

Notice of defect. There is another kind of notice besides notice of claim. This is notice of the defect which is a condition of municipal negligence. The municipality has not ordinarily the facility to watch hundreds of miles of streets and sidewalks and promptly notice all defects that storms and other exceptional conditions might create. It is therefore general law that the defect must be called to the attention of the Mayor, the City Council, or some other appropriate municipal official before the duty to repair and therefore negligence by failure to repair can begin. Nevertheless, courts in many states have invented the doctrine of constructive notice by which an unsatisfactory condition of affairs of long standing may serve in place of actual notice to found liability.

The time allowed for repair can perhaps not be stated in a statute but must be designated as a "reasonable" time. Here a problem arises in the case of small towns that do not have the funds to undertake repairs. The New York statute on this point appears to make no allowance for this fact and to hold the city, town, county or village liable if it has not performed the duty to repair a major defect causing injury.

California in 1936 developed a "minor defect" rule which limited materially the number of sidewalk cases. This rule was to the effect that when the defect is minor it warrants the inference that there was an assumption of risk or that there was no constructive knowledge, and therefore no recovery is allowed. The minor defect also covers cases where it cannot be assumed that the defect is dangerous, such as a crack in a wall. A slight difference in the level of sidewalk slabs, which often causes accidents, is considered in Los Angeles a minor defect and hence to create no liability. In Chicago, on the other hand, where the duty to maintain streets in a reasonably safe condition is strictly construed, such a difference in levels would not be considered minor and does create liability. The theory of such strict construction is that streets and highways are the most used city property, that there is always insufficient money for repairs, and that climate causes sidewalk defects. This makes the city more nearly an insurer and has raised the question in many cities whether community liability should be assumed at all. For two years New Haven denied any community liability, but then restored it. The Austin charter exempts the city from liability for sidewalk injuries. Massachusetts appears to have a $\$ 4,000$ ceiling in sidewalk cases.

The snow and ice cases give rise to similar considerations. It is difficult to prove municipal negligence in failing to remove accumulations of snow or ice, so that some argument could be made either for assuming liability completely, regardless of fault, or denying all liability. Chicago compromises by denying liability except for un- 
natural accumulations, such as those caused by negligence in maintaining drains. Over ten per cent of the Medford cases were claims arising out of injuries due to snow and ice.

The small town. It is hard to determine whether the individual is better protected in the small town than in the large city. It appears that in small towns there is an indisposition either to make claims for accidents or to press them, and it is asserted that very often such claims are advanced only by outsiders. The question arises whether, as in New York, the small town should be made wholly liable, whether an arbitrary dollar limit of town liability per person should be set, whether a state bill should cover only the larger cities, leaving the small towns to opt whether they will accept community liability in tort, or whether the town liability should be limited and the balance assumed by the state. The New York law of I94I appears to have made no differentiation in this respect between cities of the second class, counties, towns and villages. A third bill herewith submitted undertakes to limit the liability of small towns to a percentage of the tax lists, namely, two per cent, with appropriate credit for accident prevention and efficiency in avoiding tort.

Insurance. There has been some experience in the effort of various cities to insure against tort liability, but with the exception of motor vehicle damages, the experience is inconclusive. In the matter of motor vehicles insurance companies are likely to have actuarial experience so that the city might benefit from small premiums. Nevertheless, figures produced by Los Angeles would indicate that for a three-year period the insurance premiums exceeded by far the amount of tort liability. For non-vehicle claims, even insurance companies have little actuarial experience so that in the long run they are not likely to insure for lower premiums than the amount of liability they would have to meet. The experience of the five cities investigated would seem to indicate that even in the larger cities, like Chicago, tort claims would not exceed $\$ 250,000$ a year, and in most cases they would be infinitely less. Mr. Warp concludes from his study of Virginia cities that self-insurance is much cheaper than premiums paid to private companies. He has drafted a proposed Act to establish a state-wide system of municipal tort liability insurance. ${ }^{4^{a}}$ Except for such type of public insurance, such liability, carefully and justly administered, should be considered a part of the necessary overhead of administration.

It is questionable how far a state statute can undertake to define the procedure to be adopted by city attorneys in the administration of tort claims. Experience would indicate that the equipment of such an office has depended upon the financial ability of the city to supply the city attorney with facilities properly to defend and settle claims. Good administration has induced cooperation with the police and other city departments to bring about prompt investigation of claims, including the use of photographs, the interview of witnesses, and the establishment of all facts including medical examination likely to clarify the legal position. The administration varies greatly from city to city, even apart from financial considerations. But the results of

\footnotetext{
4a Warp, Municipal Tort Liability in Virginia (Bureau of Public Administration, I94I) 98, Ix3.
} 
the studies in Los Angeles, Chicago, Boston, Medford and Austin may be of some value as a guide to other cities. Research in this field is difficult and haphazard, but it may be assumed that if a state statute imposes liability for that portion of municipal activity not now covered, city attorneys will develop the necessary machinery adequately to meet the situation. The statute can furnish some guiding lines and set out the principal safeguards. Beyond that, efficiency in operating the statute to the advantage of both citizen and municipality is a question of practical administration.

\section{The State}

Four states of the United States have a constitutional prohibition against suing the state, twenty-two permit suit in some form, and twenty-two seem to be silent on the subject. Yet the situation is not as sterile as it seems. Of the four states which prohibit suit, one, Illinois, has nevertheless established a Court of Claims permitting petition even in tort and another has established a claims commission to pass upon claims with recommendation to the legislature. Among the twenty-two states that make no provision for suit against the state, the legislature often by special Act grants authority to sue in a given case. Investigation has established that the Texas legislature in a single year gave such consent in sixty-five instances and Kentucky in seventy-four..$^{5}$ In states where special legislation is constitutionally forbidden, such Acts may not be passed. But this simply means that the claims are presented to the legislature, are passed upon with as much thoroughness as possible by the committees on claims, and then submitted to the legislature for passage. These claims run all the hazards of political claims generally; whether justice is done is a matter of luck. This presupposes that such statutes are not considered special legislation; if they are, a claimant is without practical redress.

Even in the twenty-two states where suit is permitted and special Acts not prohibited, the waiver of immunity does not extend generally to tort claims. Yet this is not as absolute as it seems, since numerous statutes have adopted Section 24 of the Uniform Operators and Chauffeurs Licenses Act, making the state liable for injuries wrongfully inflicted by the publicly employed operators of public motor vehicles, or making the state liable for injuries arising out of defects in state highways. Liability in contract, express or implied, and in eminent domain is common.

In the three states which provide for judicial adjudication before a Court of Claims, Illinois, Michigan and New York, Illinois gives the Court jurisdiction over "all claims and demands, legal and equitable, liquidated and unliquidated, ex contractu and ex delicto, which the state as a sovereign commonwealth should in equity and good conscience discharge and pay." Michigan gives its court jurisdiction "to hear and determine all claims and demands, liquidated and unliquidated, ex contractu and ex delicto against the state and all its departments, commissions, boards, institu-

\footnotetext{
'See Study of Nebraska Legislative Council, REP. No. 17 , Settlement of Claims against the State (194I) (hereinafter referred to as "Neb. Report") 8.

Ill. Laws I9I7, p. $325, \$ 6$.
} 
tions, arms or agencies."' In New York, the broadest of all, jurisdiction extends to all cases arising from the management of canals, defects in highways, the appropriation by the state of private lands, the elimination of grade crossings, erroneous payment of taxes, contracts with the state, and cases of tort of state officers and employees in so far as they would give rise to actions against private individuals and corporations. ${ }^{8}$ As will be observed in the Appendix, this broad liability has not cost New York any excessive sums; limitations are worked out by the courts.

It is perhaps better not to use the Illinois and Michigan form of expression, liability ex delicto, since this is likely to hamper any growth in the law. One of the problems in this field is to persuade the courts to expand the conception of moral obligations by recognizing the duty of the state to make compensation, whereupon the moral obligation will have become a legal one. Even where moral obligations are assumed, differences may arise as to what is a "moral obligation." For example, a New York local Act provided for compensation to bystanders injured by policemen engaged in attempting to make arrests. A policeman, in tracking down a lawbreaker, unintentionally shot a Miss Evans in the foot, whereupon the Comptroller disallowed the claim, not merely because it involved no legal obligation but because, in his view, it did not even involve an equitable or moral obligation which the city was authorized to discharge. The Appellate Division agreed unanimously. ${ }^{9}$ Fortunately, the Court of Appeals, by Chief Judge Pound, unanimously reversed, ${ }^{10}$ concluding that the times and public policy had changed, that there was a moral and equitable if not a stronger obligation to assume such liability, and this even though the policeman's shot might not be considered a fault or tort but a perfectly faultless accident. Indeed, several states admit liability for mob violence and errors in the conviction of innocent men, which cannot be considered strictly official torts. But if we would allow opportunity for growth, it might be better to express the desired liability without using the word "tort" and simply assume liability, as does the federal bill, for the "negligent or wrongful act or omission of any employee of the government while acting within the scope of his office or employment." The federal bill adds: "under circumstances where the United States, if a private person, would be liable to the claimant for such damage, loss, injury or death, in accordance with the law of the place where the act or omission occurred."

Procedure for settlement of claims. Aside from the legislative private bill, or reference to a Court of Claims for the advice of the legislature, nine states have adopted an administrative settlement by Claims Commission. This usually consists of a few state officials, and while not a court, acts more judicially in determining the validity of a claim than might a legislative committee. Its findings are as a rule advisory only, and a dissatisfied claimant can generally present his claim to the legislature or to a court, where permissible. The cost of administration is trifling, since the mem-

${ }^{7}$ Mich. Laws 1939, No. 135, \$8, as amended by No. 59 of 194x. See Report of the [Mich.] Court of Crams, for biennium ending Dec. 3I, 1940.

${ }^{8}$ N. Y. Laws I939, c. 860 , art. II, $\$ 9$.

${ }^{\circ}$ Evans v. Berry, 236 App. Div. 334,258 N. Y. Supp. 473 (I933).

${ }^{10} 262$ N. Y. 61,186 N. E. 203 (I933). 
bers of the Board are usually state officials already receiving compensation as such. They submit their recommendations to the legislature. Such a body is not the most efficient, since the members have other duties to perform; it has not the dignity or the equipment of a court, and can probably not make independent investigations or even enlist the support of other bodies. It is probably suitable to small states only.

The Administrative Board, as formerly in Michigan and the State Board of Control, as in California, may however play an important part in the administration of tort claims. It could unify the practice throughout the State, make small administrative settlements so as to relieve the courts-as can the federal departments up to $\$ 1,000$-, subject to report to the legislature or subject to legislative approval, it could institute uniform investigating methods to establish the validity of claims, adopt uniform rules for preventing and reporting accidents, with photographs and medical and other examination of victims and witnesses, and in other ways helpfully regularize the practice and administration of tort liability. Such an administrative body is appropriate, whether the state establishes a Court of Claims for suits above $\$ 2,500$ (or less) or allows the regular courts to be invoked for such purpose. Courts are obviously desirable, since they develop uniform rules of law and procedure, render final judgments not subject to legislative disallowance although requiring appropriations, and are not subject to political influence or ephemeral political considerations. In New York the Court of Claims consists of five full-time judges, appointed by the Governor for nine-year terms. In Illinois, there are three judges whose terms coincide with that of the appointing Governor. The federal Court of Claims was probably the model for these courts, although the federal judges are appointed for life. In Michigan, the Court of Claims established by the Act of 1939 is presided over by one regular circuit judge, designated by the presiding circuit judge of the state.

The cost to the state of permitting suit in tort is relatively small. Of the Igr cases filed in the Michigan Court of Claims during the first two years of its existence, ${ }^{2} \mathrm{I}_{\mathrm{I}}$ were adjudicated. Of these, 75 were allowed in whole or in part, and 66 denied. The total amount claimed in these I4I cases was $\$ 356,893.3 \mathrm{I}$, the amount allowed $\$ 5^{6}$, 602.72 , or only $15.85 \%$ of the amount claimed. These include claims in categories not strictly tort. ${ }^{11}$ In New York ${ }^{12}$ during the ten-year period from 1928 to 1937 , the New York Court of Claims disposed of 6,070 claims, not all in tort, totaling $\$ 85,507,393.7 \mathrm{r}$. Of this number, 3,07I claims were dismissed. The awards in the remaining 2,999

\footnotetext{
${ }^{11}$ Before 1939, when the Court of Claims was established, Michigan had a state administrative board consisting of the Governor, Secretary of State, Treasurer, Attorney General, Auditor General, State Highway Commissioners and Superintendent of Public Instruction, with power to hear the following types of claims: ( $I$ ) emergency claims, such as claims arising from repair of state buildings because of fre, etc.; (2) claims of state employees for injuries; (3) claims arising from acts or omissions of state cmployecs or institutions; (4) claims arising from negligent highway construction; (5) claims of national guardsmen; and (6) claims of dependents of members of the state police force. Allowed claims were certified to the auditor general, who then drew his warrant on the state treasurer. Cf. Neb. Report, at 28 . The Michigan Court of Claims took over the work of the State Administrative Board with wider jurisdiction (Act I35 of 1939). The cost of operating the Court of Claims is only $\$ 4,900$ per year; the only full-time employee is the Clerk of the Court, Mr. William $\mathrm{T}$. Caughey, who supplied the statistical information.

${ }^{22} \mathrm{Cf}$. appendix to MacDonald, The Administration of a Tort Liability Law in New York, supra p. 281.
} 
claims totaled $\$ 15,165,207.50$, or less than $18 \%$ of the amount claimed. ${ }^{13}$ The statistics for tort claims alone under the Canal and Highway Acts, as partly merged in the Tort Claims Act of I929-a monument to Attorney General Ward-show even a lower percentage of cost to the state.

The appended draft of a bill covering state liability alone, presented in alternative form, endeavors to carry out the ideas presented above. It is based mainly on existing legislation or legislative bills, although in some cases models for a single section find their source in different acts or bills.

\section{Tort Liability of State Alone}

(Model A)

Section $[r]$. The state hereby waives its immunity. for the torts of its officers and employees and consents to have its liability for such torts determined in accordance with the same rules of law as apply to an action in the (highest court of original jurisdiction) against an individual or a corporation; the state hereby assumes liability for such acts and jurisdiction is hereby conferred upon the Court of Claims to hear and determine all claims against the state to recover damages for injuries to property or for personal injury caused by the misfeasance (non-feasance?) or negligence of the officers or employees of the state while acting within the scope of their authority or employment.

[This follows the model of the broad Act of New York of April 10, 1929, Laws of 1929, c. 467.$]$

Alternative form, following more closely the federal tort claims bill:

Section $[I A]$. Subject to the limitations of this Act, the State of - shall be liable in an amount not exceeding Twenty-five Thousand Dollars (? $)^{\mathbf{1 4}}$ to every person who sustains damage to his property, or in an amount not exceeding Seventy-five Hundred Dollars to every person who sustains personal injury or death if the damage to the property or injury or death was either ( $I$ ) proximately caused by the wrongful or negligent act or omission of any officer or employee of the state acting within the scope of his authority, or (2) proximately caused by any defect or insufficiency in any public streets, highways, buildings, grounds, works, property, machinery, vehicle or appliance, provided such defect or insufficiency was due to the wrongful or negligent act or omission of such officer or employee. ${ }^{15}$

Section $[2 A]$. Except as otherwise herein provided, the party injured may sue and recover judgment against the state in the Court of Claims (or similar body in the state) or any other court having jurisdiction of civil suits against the state.

Section [ $3 A$ ]. The State Administrative or Control Board (as in California, or other fiscal or administrative body to be selected) is hereby vested with power and authority to hear, consider and determine claims against the state presented to said Board and, subject to the provisions hereinafter set forth, may settle, adjust or allow any claim not exceeding Twenty-five Hundred Dollars in amount, payment of which, if under One Thousand Dollars, may be ordered from the general fund.

\footnotetext{
${ }^{13}$ Neb. Report, at 17 , citing Barretr, Court of Claims of the State of New York, Its History, STRUCTURE AND WoRK.

16 The $\$ 7,500$ limitation of the federal bill for property damage seems too small.

${ }^{20}$ Query: Does this cover nuisances, overflows by diversion of natural streams and latent defects in public property not specifically attributable to the negligence of any particular officer or employee?
} 
Section $[4 A]$. No claim shall be considered under this Act unless notice thereof setting forth the time, place and cause of the alleged damage, loss, injury or death shall be presented in writing by the claimant or, in the case of a joint claim, by any one of the claimants or, in case of death, by an executor or administrator, to the State Administrative Board (or other fiscal or administrative body to be selected) if caused by an officer, commission, department, board, institution, agent or employee of the state, within thirty (sixty?) days from the date of the occurrence of the event out of which the claim arose.

Section [5A]. No claim shall be allowed under this Act in the event that the claimant or his principal or any agent, servant or employee of such claimant or his principal, was guilty of contributory negligence in causing the loss or injury or in the event that the loss or injury was proximately caused by the intoxication or willful misconduct of any such person. But the fact that the claim arose out of what may be denominated a governmental function shall not be a bar to any claim.

Section [6A]. Notice of claim having been filed as provided for in Section [4A], the claim itself shall be filed, verified under oath, within six months after the occurrence of the event that is the basis of the claim, setting forth in detail the facts relied upon in support of the claim and specifically the alleged wrongful or negligent acts or omissions on which it is based. If the claimant does not accept the amount, not in excess of Twentyfive Hundred Dollars, allowable by the said Board, as provided in Section [IA] above, he may within six months of the filing of his claim or within six months of the date of the decision referred to in Section - hereinafter, institute an action against the state in the Court of Claims (or other court of competent jurisdiction). But jury trial shall not be permitted.

Section [ $7 A]$. The Court of Claims (or other board or court of competent jurisdiction provided by the state) shall have jurisdiction to hear and determine any claim in excess of Twenty-five Hundred Dollars allowable under the provisions of this Act, subject to the following limitations: (I) that no such suit may be maintained under the claim has been duly filed with the State Administrative Board and its decision obtained thereon; provided that if such decision be delayed more than four months from the date of filing then the suit may be brought without awaiting such decision; (2) that no suit shall be instituted after the expiration of six months from the date of the mailing of a copy of such decision to the claimant. The State Administrative Board (or other proper fiscal or administrative body) shall have the power and authority to compromise any claim in an amount not exceeding Twenty-five Hundred Dollars at any time prior to the rendition of final judgment by the Court of Claims, and any such claim shall be certified as provided in the following Section. The Supreme Court may on certiorari review all judgments rendered by the Court of Claims under this Act.

Section $[8 \mathrm{~A}]$. Any claim allowed under this Act in excess of One Thousand Dollars shall be certified by the State Administrative Board or the Court of Claims as the case may be, to the state legislature for its consideration and action, and such certificate shall contain a statement of the facts and the reasons for the allowance of the claim and for deductions, if any. Any amount found due and paid under this Act shall forever discharge the state from any claim or demand on account of the loss or injury involved in the said claim. The right of either House of the legislature is especially reserved to return to the State Administrative Board any claim settled by it, for further examination and report or to refer any such claim to the Court of Claims for further investigation to determine the facts and law and report its conclusions thereon. Before any claim is paid there shall be withheld from the amount allowed the amount of any liquidated claim of the state against the claimant.

Seation $[9 A]$. The provisions of this Act shall not apply to (a) any claim for loss, 
injury or destruction of property or for injury or death incurred by any member of the militia or National Guard when called into the service of the state or incurred by any officer or employee of the state to whom the Workmens Compensation Act may apply; (b) any claim for injury to or death of a prisoner; (c) any claim arising out of any alleged wrongful or negligent act or omission of any employee of any state, county or municipal hospital, dispensary, or institution, or of any physician, surgeon, nurse or orderly in connection with the rendition of medical or surgical treatment; (d) any claim for injuries or death arising out of assault, use of excessive force, battery, false imprisonment, false arrest, malicious prosecution, abuse of process, libel, slander, misrepresentation, deceit, interference with contract rights, or any criminal act; (e) any claim on account of the defect or alleged defect of any act of the legislature or executive order of the state government, or of any administrative order or regulation of any commission, department, board, institution, agent or employee of the state.

Section [ $10 A]$. If the damage, loss, injury or death is caused under circumstances creating a legal liability, jointly with the state, upon some person other than a public officer, commission, department, board, institution, agent or employee of the state, then and in that event the award or judgment against the state shall be only for its pro rata share of the damages.

Section [ $I I A]$. The State Administrative Board shall provide rules and regulations for the investigation and report of any accident, occurrence or event which may become the basis of a claim under this Act and for the filing of notice of claim and of claims of damage, loss, injury or death.

Section $[12 A]$. No claim shall be allowed under this Act on behalf of any insurance company by right of subrogation where claimant was insured against the loss sustained;16 provided that in the event that any claimant under this Act shall have collected or shall be entitled to collect insurance against the damage, loss, injury or death involved in such claim, the amount of insurance so collected or collectible by him shall be deducted from the amount recoverable under this Act.

Section $[13 A]$. The state shall have the right to be reimbursed by any officer, agent or employee willfully causing the damage, loss, injury or death giving rise to any claim against the state under this Act.

Section $[14 A]$. An officer, agent or employee of the state not willfully causing the damage, loss, injury or death giving rise to a claim against the state and made a defendant jointly with the state under this Act, and any officer, agent or employee of the state not willfully causing damage, loss, injury or death who, acting within the scope of his authority, has been sued for personal liability for the damage, loss, injury or death so caused, shall, if the Attorney-General considers the act as performed within the line of duty, be defended by the Attorney-General, and the State Administrative Board shall, if it considers the defendant's case meritorious, pay any judgment that may be found against him. The state is hereby authorized to purchase insurance against the personal liability of all officers, agents or employees of the state while acting within the scope of their authority or employment.

Section [ $15 A]$. In any claim under this Act where recovery is had, the fees of the claimant's attorney or attorneys shall be in such reasonable amount not exceeding twenty percent of the amount recovered as shall be fixed by the State Administrative Board or the Court of Claims, as the case may be. Any attorney who charges, demands, receives or collects for services rendered in connection with such claim any amount in excess of that allowed under this Section, if recovery be had, shall be guilty of a misdemeanor and shall,

${ }^{10}$ There is some expert objection to this provision; it is not in the federal bill. 
upon conviction thereof, be subject to a fine of not more than Two Thousand Dollars and imprisonment for not more than one year, or both.

Section $[16 \mathrm{~A}]$. No claim shall be allowed under this Act to any person who shall willfully, knowingly and with intent to defraud have claimed more than was justly due in respect of such claim or shall have presented any false evidence in support thereof.

Section [ $x 7 A]$. Any claim for damage to property arising under the terms of this Act where the amount of injury is claimed to be in excess of Twenty-five Thousand Dollars shall be submitted to the legislature which may, however, refer the said claim to the Court of Claims for investigation and hearing and report to the legislature.

\section{Municipal Corporattons-Counties, Cities, School Districts and Other Political Subdivisions}

The factors which helped to break the bonds of municipal irresponsibility were the increasing municipal ownership of property, especially when connected with injuries to private property, legislation imposing liability, within certain limitations, for the care of streets and highways, and legislation imposing liability for injuries in flicted by the drivers of municipal and state automobiles. These admissions of liability helped to dissipate distinctions that had been deemed fundamental and helped to expose their artificiality. It was perhaps not unnatural that injuries to private property should first be excepted from the rule of immunity, because the principle of compensation for public taking of private property by eminent domain had been written large in the individualist laissez-faire economy of the eighteenth and nineteenth centuries; and, incidentally, we may be pardoned a doubt whether the current world-wide attack upon this institution will prove to have been socially constructive. From the taking of property to the injuring of property is but a slight, often a metaphysical or nominal, step, so that the tort of nuisance in the maintenance of public property received wide application. But the relatively slow development of the law of personal injuries, not to speak of liability for death, served in general to clothe with immunity damage to the person caused by the defective condition of public property, although it would have required no strain on the imagination to conclude that the ownership of public buildings was a "proprietary" function, imposing liability, regardless of the purpose for which the building was used. Yet with the increase in movables and the broadening concept of injuries to the person, defects in public property served occasionally to impose liability upon the public treasury, even as against the person. To be sure, difficulty was always found in distinguishing nuisance from negligence, for which latter, except in revenue-producing property, the concept of "governmental" function was still frequently invoked to decree immunity.

While the view that negligence in the care and use of public property involves liability has by no means been generally adopted, a significant beginning was made by the state statutes which impose municipal-although not always county-liability for injuries arising out of the defective condition of streets and highways. This function, before the statutes, had generally been deemed "governmental," but the fact that statutes imposing liability in this sphere were so widely adopted negatived the notion that immunity was inherent or fundamental. To be sure, the liability is 
usually, and rightly it is believed, a limited one, conditioned on such requirements as notice, clear proof of municipal negligence after opportunity to correct the defect, or positive misfeasance, absence of contributory negligence, liability to travelers only, and other conditions. Here the doctrine of nuisances has served to weaken the basis of liability for negligence, many courts construing negligence most strictly in favor of the city. In the construction of public works, the property concept, both as to the source and incidence of the injury, again played its part. Nuisances, when established, imposed liability to property owners affected, personal injuries only by way of exception. More justifiable distinctions were here made between (a) failure to provide public works or deficiencies in plan, considered legislative, deliberative and not susceptible of classification as torts, and (b) negligent execution or administration of public works, although courts are by no means in agreement as to where the line between them shall be drawn. Yet the distinction between planning and administration may be worthy of development as rational and just, even in its application to other aspects of public service. The analogy to streets and highways has enabled some courts to classify parks and playgrounds as "corporate" or "proprietary" activities, predicating liability.

But it was the motor vehicle which made the most effective contribution to the dissipation of the distinction between corporate and governmental functions. During the last decade or two, numerous states have enacted statutes imposing liability on cities and even on the state for the negligent operation by public officers of governmentally owned motor vehicles, regardless of the particular public service in which the vehicle is employed. Sometimes police or fire service is particularly mentioned. These statutes constitute a recognition of the fact that the injury sustained by the citizen through the operation of governmental machinery is more important as a criterion of liability than is the particular department by which the injury was inflicted. A motor vehicle in the police, fire, education or health service has the same relation to the public purse and the injured citizen as has a similar vehicle engaged in the transportation, water or gas service. The character of the injury, the question whether a private corporation under similar circumstances would be liable in tort, whether the injurious act was an administrative act within the scope of the officer's or employee's general authority or employment, should be the first, although not the only, test of liability. The Ohio Supreme Court attempted to apply these tests without statute, but this seemed too radical a departure from tradition to a succeeding court and the conclusion was overruled, although Florida, it is believed, has adhered to its view that the first Ohio decision was sound. ${ }^{16^{a}}$

Mob violence statutes are now accepted as traditional, although they involve social and legal theories far more advanced than any community assumption of liability in tort. California, New York, Wisconsin and North Dakota make compensation for certain flagrant errors in criminally convicting the wrong person, although tort may be unprovable. Minnesota and California provide for the defense of employees of the

${ }^{162}$ Ohro CoDe (1936) $\$ 37$ I 4-r, after providing for liability for negligence in driving municipal motor vehicles, excepts inter alia fire vehicles proceeding to a fire. 
police and fire and other departments by the district attorney and their indemnification for judgments against them under certain conditions. Washington and other states have assumed a more direct liability for the torts of certain public officers. In California, the street and highway liability above mentioned is extended to the dangerous or defective condition of public buildings, grounds, works and property of county, city or school district, provided there was knowledge or notice of the defect or condition which the officer in charge failed after reasonable opportunity to remedy. If the suit is brought against the officer, even for negligence or carelessness, the district attorney defends the suit. Connecticut holds harmless the operator of a motor vehicle used for fire fighting. Provision for insuring the official or community liability is becoming common. A few recent statutes exempting cities from liability for negligence in the operation of municipal airports are distinctly contrary to the modern trend of legislation.

Cost. Mr. George A. Warp of Virginia has made a study of the financial burden imposed on different cities by the present assumption of tort liability. ${ }^{10^{\mathrm{b}}}$ This is admittedly somewhat limited, but it probably would not be 'greatly extended by making the city liable generally for the tortious performance of governmental functions. Mr. Warp finds that in I940 the cost of tort claims to Richmond, Virginia, was $\$ 21$ per 10,000 population, and over a ten-year period, \$ 443 per ro,000 population. In Norfolk for r940 it was $\$ 36$; in Roanoke, $\$ 42$; in Lynchburg, $\$ 540$; in other Virginia cities, \$90; and in the Virginia towns, \$68. In Madison, Wisconsin, it was $\$ 99$ per I0,000 population; in Los Angeles, \$r80; in Austin, Texas, \$337; in Boston, \$857; and in Medford, $\$ 1,6 r 8$. The smaller of these amounts is trifling. Even the larger sums impose a relatively minor liability.

The following draft is suggested:

Tort Liability of County, City, School District, District Established by Law and Other Political Subdrvisions of the State

Section $[I B]$. As used in this Act, the term "municipal corporation" includes every county, city, school district, district established by law and other political subdivision of the state.

Section $[2 B]$. Subject to the limitations of this Act, every municipal corporation of this state shall be liable in an amount not exceeding Twenty-five Thousand Dollars (?) to every person who sustains damage to his property, or in an amount not exceeding Seventyfive Hundred Dollars to every person who sustains personal injury or death if the damage to the property or injury or death was either $(I$ ) proximately caused by the wrongful or negligent act or omission of any officer of the municipal corporation acting within the scope of his authority, or (2) proximately caused by any defect or insufficiency in any public streets, highways, buildings, grounds, works, property, machinery, vehicle or appliance, provided such defect or insufficiency was due to the wrongful or negligent act or omission of such municipal corporation, officer or employee. ${ }^{\mathbf{1 7}}$

Section $[3 B]$. Except as otherwise herein provided, the party injured may sue and

${ }^{160}$ Warp, The Law and Administration of Municipal Tort Liability (1924) 28 VA. LAw Rev. 360 , at 376.

${ }^{17}$ Stupra n. I5. 
recover judgment against the municipal corporation in any court having jurisdiction of civil suits against the municipal corporation.

Section $[4 B]$. The municipal corporation is hereby vested with power and authority to hear, consider and determine claims against the municipal corporation presented to said municipal corporation and, subject to the provisions hereinafter set forth, may settle, adjust or compromise any claim, if the settlement or compromise is approved by the law officer and the governing body of the municipal corporation. The municipal law officer alone may settle or compromise any claim if the amount allowed is less than Two Hundred and Fifty Dollars; an annual report of such settlements or compromises shall be filed with the governing body of the municipal corporation.

Section $\left[5^{B}\right]$. No claim shall be considered under this Act unless notice thereof setting forth the time, place and cause of the alleged damage, loss, injury or death shall be presented in writing by the claimant or, in the case of a joint claim, by any one of the claimants or, in case of death, by an executor or administrator, to the municipal corporation within thirty (sixty?) days from the date of the occurrence of the event out of which the claim arose.

Section [6B]. No claim shall be allowed under this Act in the event that the claimant or his principal or any agent, servant or employee of such claimant or his principal, was guilty of contributory negligence in causing the loss or injury or, in the event that the loss or injury was proximately caused by the intoxication or willful misconduct of any such person. But the fact that the claim arose out of what may be denominated a governmental function shall not be a bar to any claim.

Section $[7 B]$. Notice of claim having been filed as provided for in Section [6B], the claim itself shall be filed, verified under oath, within six months after the occurrence of the event that is the basis of the claim, setting forth in detail the facts relied upon in support of the claim and specifically the alleged wrongful or negligent acts or omissions on which it is based. If the claimant does not accept the amount offered in settlement by the said municipal corporation he may within six months of the filing of his claim or within six months of the date of the decision of said municipal corporation institute an action against the municipal corporation in the (court of competent jurisdiction). But jury trial shall not be permitted, unless expressly demanded in a particular case by the defendant municipal corporation.

Section $[\delta B]$. The court shall have jurisdiction to hear and determine any claim filed under this Act, subject to the following limitations: ( $r$ ) that no such suit may be maintained until the claim has been duly filed with the municipal corporation and its decision obtained thereon; provided that if such decision be delayed more than four months from the date of filing then the suit may be brought without awaiting such decision; (2) that no suit shall be instituted after the expiration of six months from the date of the mailing of a copy of such decision to the claimant. The municipal corporation shall have the power and authority to compromise any claim at any time prior to the rendition of final judgment by the court.

Section $[g B]$. Any amount found due and paid under this Act shall forever discharge the municipal corporation from any claim or demand on account of the loss or injury involved in the said claim. Before any claim is paid there shall be witheld from the amount allowed the amount of any liquidated claim of the municipal corporation against the claimant.

Section [ $I O B]$. The provisions of this Act shall not apply to (a) any claim for loss, injury or destruction of property or for injury or death incurred by any member of the militia or National Guard when called into the public service or incurred by any officer or employee to whom the Workmen's Compensation Act may apply; (b) any claim for injury 
to or death of a prisoner; (c) any claim arising out of any alleged wrongful or negligent act or omission of any employee of any state, county or municipal hospital, dispensary, or institution, or of any physician, surgeon, nurse or orderly in connection with the rendition of medical or surgical treatment; (d) any claim for injuries or death arising out of assault, use of excessive force, battery, false imprisonment, false arrest, malicious prosecution, abuse of process, libel, slander, misrepresentation, deceit, interference with contract rights, or any criminal act; (e) any claim on account of the defect or alleged defect of any act of the governing body of the municipal corporation or of any administrative order or regulation of any commission, department, board, institution, agent or employee of the municipal corporation.

Section $[I x B]$. If the damage, loss, injury or death is caused under circumstances creating a legal liability, jointly with the municipal corporation, upon some person other than a public officer, commission, department, board, institution, agent or employee of the municipal corporation, then and in that event the recovery against the municipal corporation shall be only for its pro rata share of the damages.

Section $\left[r_{2} B\right]$. The municipal corporation shall provide rules and regulations for the investigation and report of any accident, occurrence or event which may become the basis of a claim under this Act and for the filing of notice of claim and of claims for damage, loss, injury or death.

Section $\left[13^{B}\right]$. No claim shall be allowed under this Act on behalf of any insurance company by right of subrogation where claimant was insured against the loss sustained; ${ }^{18}$ provided that in the event that any claimant under this Act shall have collected or shall be entitled to collect insurance against the damage, loss, injury or death involved in such claim, the amount of insurance so collected or collectible by him shall be deducted from the amount recoverable under this Act.

Section $[14 B]$ : The municipal corporation shall have the right to be reimbursed by any officer, agent or employee willfully causing the damage, loss, injury or death giving rise to any claim against the municipal corporation under this Act.

Section $\left[15^{B}\right]$. An officer, agent or employee of the state or municipal corporation not willfully causing the damage, loss, injury or death giving rise to a claim against the municipal corporation and made a defendant jointly with the municipal corporation under this Act, who, acting within the scope of his authority, has been sued for personal liability for the damage, loss, injury or death so caused, shall, if the law officer of the municipal corporation considers the act as performed within the line of duty, be defended by the said law officer, and the municipal corporation shall, if it considers the defendant's case meritorious, pay any judgment that may be found against him. The state hereby authorizes its municipal corporations, as defined in this Act, to purchase insurance against the personal liability of all officers, agents and employees thereof incurred while acting within the scope of their authority or employment.

Section $[r 6] B$. In any claim under this Act where recovery is had, the fees of the claimant's attorney or attorneys shall be in such reasonable amount not exceeding twenty percent of the amount recovered as shall be fixed by the municipal corporation or the court, as the case may be. Any attorney who charges, demands, receives or collects for services rendered in connection with such claim any amount in excess of that allowed under this Section, if recovery be had, shall be guilty of a misdemeanor and shall, upon conviction thereof, be subject to a fine of not more than Two Thousand Dollars and imprisonment for not more than one year, or both.

Section $\left[r^{B}\right]$. No claim shall be allowed under this Act to any person who shall will-

${ }^{28}$ This provision meets objections from some experts. 
fully, knowingly and with intent to defraud have claimed more than was justly due in respect of such claim or shall have presented any false evidence in support thereof.

Section $[I \delta B]$. Municipal corporations in this state may adopt rules and regulations, not inconsistent with the provisions of this Act, for the administration of the liability herein assumed.

In case it is thought desirable specifically to provide for liability for publicly owned or controlled motor vehicles, for mob violence, for stray bullets of police officers, and for assistance to police officers, the following models for statutes are submitted.

\section{Motor Vehicles}

Section $\left[{ }_{I} C\right]$. This state and every county, city, municipal or other public corporation within this state employing any operator or chauffeur shall be jointly and severally liable with such operator or chauffeur for any damages caused by the negligence of the latter while driving a motor vehicle upon a highway in the course of his employment. ${ }^{19}$

Liability of state, districts and political subdivisions for negligent operation of motor vehicles. Hereafter, the state, and every county, city and county, municipal corporation, the state compensation insurance fund, irrigation district, school district, district established by law and political subdivision of the state owning any motor vehicle shall be responsible to every person who sustains any damage by reason of death, or injury to person or property as the result of the negligent operation of any said motor vehicle by an officer, agent, or employee or as the result of the negligent operation of any other motor vehicle by any officer, agent or employee when acting within the scope of his office, agency or employment; and such person may sue the state, county, city and county, municipal corporation, the state compensation insurance fund, irrigation district, school district, district established by law and political subdivision of the state, as the case may be, in any court of competent jurisdiction in this state in the manner directed by law. ${ }^{20}$

Actions for injuries caused by motor vehicles owned or requisitioned by the state or its municipal corporations. Any person injured in person or property through the negligence of any state official or employee when operating a motor vehicle owned or requisitioned by the state or its municipal corporations, whether or not insured by the state against personal injuries or property damage, shall have a right of action against the state or appropriate municipal corporation to recover damages for such injury. ${ }^{21}$

Transportation of school children. In any action brought by any person for personal injuries received while being transported to or from school in a vehicle owned, leased or. hired by, or operated under contract with, any town, school district or other municipality, it shall be no defense that such transportation is in the line of governmental duty. In any such action brought against any town, school district or other municipality, it shall be no defense that the transportation was being provided by an independent contractor. ${ }^{22}$

Liability for damage caused by motor vehicle used for fire fighting. The municipality for whose benefit fire fighting apparatus is maintained or fire prevention service is being rendered shall indemnify and hold harmless the operator of any motor vehicle, used exclusively for fire fighting purposes, from any damage that such operator may sustain because of his legal liability for injury or damage to the person or property of another, including the causing of death, by reason of the operation of such motor vehicle, provided

${ }^{10}$ This is Section 24 of the UNiform Operstors and Chatffetro Licenses Act, adopted by several states.

${ }^{30}$ This comes from CAL. Crv. Code (Deering, I93I), $\$$ I71 $4 \frac{112}{2}$, p. 66I; Stat. I93I, p. 168.

${ }^{21}$ Based on Conn. Laws 1927, c. 209.

${ }^{22}$ Id. 1929, c. 38. These sections are based on Conn. Gen. Star. 1930, c. 319, $\$ \$ 5988,5989$, p. 1869 . 
such injury, damage or death was not caused by the wilful or wanton misconduct of such operator and provided, at the time of causing the injury, damage or death, such operator was acting in the performance of his duties and within the scope of his employment. ${ }^{22^{a}}$

\section{Mob Violence}

Section $[I D]$. Any person or persons composing a mob under the provisions of this Act, who shall by violence inflict material damage to the property or serious injury to the person of any other person, by violence and without authority of law, shall be deemed guilty of a felony, and shall suffer imprisonment in the penitentiary not exceeding five years; and any person so suffering material damage to property or injury to person by a mob shall have an action against the county, park district or city in which such injury is inflicted, for such damages as he may sustain to an amount not exceeding Ten Thousand Dollars.

Section $[2 D]$. The surviving spouse, lineal heirs, or adopted children of any such other person or persons, who, before the loss of life, were dependent for support upon any other person who shall hereafter suffer death by lynching at the hands of a mob, in any county, park district or city in this state, may recover from such county, park district or city damages for injury sustained by reason of the loss of life of such person, to a sum not exceeding Ten Thousand Dollars. ${ }^{23}$

\section{Alternative}

Section [ $I E]$. Any person or persons composing or being one of a mob, under the provisions of the laws of this state, and who shall, by violence, inflict material damage on the property of another, or serious injury to the person of another, upon the pretense of exercising correctional powers over such person or persons, by violence, and without authority of law, shall be deemed guilty of a felony and shall suffer imprisonment for any indeterminate period not exceeding ten years and not less than three years, and the serving of such sentence shall be mandatory.

Section $[2 E]$. The surviving spouse, lineal heirs, parents or adopted children of any such other persons, who, before loss of life, were dependent for support upon any other person who shall hereafter suffer death by lynching at the hands of a mob, in any county, city or town of this state, may recover from the county, city or town where the lynching occurred, for injuries sustained by reason of the loss of life of such person, a sum of not to exceed Ten Thousand Dollars.

Section [3E]. Any person who is assaulted and lynched by a mob and who is injured but does not suffer death may have an action against the county or city where such injury occurs and may recover a determinate sum not to exceed Ten Thousand Dollars.

Section $[4 E]$. Should any property be destroyed or injured as a result of the actions of a mob, the county or city in which such property is destroyed shall be subject to an action therefor by the party whose property was destroyed.

Section $[5 E]$. That any collection of individuals, five or more in number, assembled for the unlawful purpose of offering violence to the person or property of any one supposed to have been guilty of a violation of the law, or for the purpose of exercising correctional powers or regulative powers over any person or persons by violence, and without lawful authority, shall be regarded and designated as a "mob" or "riotous assemblage."24

${ }^{228}$ Conn. Gen. Stat., c. 32, \$139e (Supp. 1939).

${ }^{23}$ Based on Ill. Laws I931, p. 454, REv. STAT. (I935), c. 38. Twenty-three states have such statutes, some covering property damage or personal injury only.

${ }_{24}$ Based on Ind. Laws 1931, c. 85, repealed by Laws 1932, c. 69. 


\section{Municipal Liability for Stray Bullets Shot by Policemen in Pursuit of Criminals but Unintentionally Hitting Bystanders or Other Private Citizens}

Section $[I F]$. The [county, city,] municipal corporation, [school district, district established by law or other political subdivision] is hereby authorized and empowered in its discretion to make an award to a person who has been or shall be injured by a police officer engaged in arresting any person or in re-taking any person who has escaped from legal custody or in executing any legal process.

\section{Alternative}

Section $[1 G]$. Any person injured by a police officer while such officer is engaged in arresting a person or in re-taking a person who has escaped from legal custody or in executing any legal process may bring claim against the [county, city,] municipal corporation, [school district, district established by law or other political subdivision] employing such policeman.

\section{Assistance to Police Officer}

Section $\left[{ }_{I} H\right]$ ]. Every [county, city,] municipal corporation, [school district, district established by law or other political subdivision] shall be liable in damages to any person whose motor vehicle has been commandeered by any officer of such [county, city,] municipal corporation, [school district, district established by law or other political subdivision] engaged in pursuing an alleged violator of the law whereby personal injury or property damage is caused by said motor vehicle, except when the operator of the vehicle was grossly negligent.

\section{Alternative}

Section $[I J]$. Any person who sustains a personal injury or property damage while engaged in aiding an officer make an arrest under command or orders of said officer, shall be compensated by the [county, city,] municipal corporation, [school district, district established by law or other political subdivision] for the injury or damage so sustained.

In case a special provision is desired covering defective condition of public streets and property, the following may be suggested.

\section{Liability for Negligence in Care of Public Property}

Section $[r K]$. Counties, municipalities and school districts shall be liable for injuries to persons and property resulting from the dangerous or defective condition of public streets, highways, buildings, grounds, works and property in all cases where the governing or managing board of such county, municipalities, school district, or other board, officer or person having authority to remedy such condition, had knowledge or notice of the defective or dangerous condition of any such street, highway, building, grounds, works or property and failed or neglected, for a reasonable time after acquiring such knowledge or receiving such notice, to remedy such condition or failed and neglected for a reasonable time after acquiring such knowledge or receiving such notice to take such action as may be reasonably necessary to protect the public against such dangerous or defective condition. ${ }^{25}$

\section{APPENDIX \\ New York Statutes}

Since New York is perhaps the state most advanced in the admission and administration of tort liability, and since it has in recent years revised its public liability

${ }^{25}$ Based on Cal. Pub. Linaility Act, Cal. Stat. 1923, p. 675, Gen. Laws (Deering, I937) Act 56r9. 
statutes, there may be some justification in taking a few pages to reprint a few of the important New York statutes bearing on the liability in tort of cities, towns, villages and public authorities in that state. They may be preferred as models to the drafts presented above.

\section{GENERAL MUNICIPAL LAW}

Sec. 50-a. Municipal Liability for negligent operation of vehicles. Every city, town and village shall be liable for the negligence of a person duly appointed by the governing board or body of the municipality, or by any board, body, commission or other offeer thereof, to operate a municipally owned vehicle within the state in the discharge of a statutory duty imposed upon the municipality, provided the appointec at the time of the accident or injury was acting in the discharge of his duties and within the scope of his employment. Every such appointee shall, for the purpose of this section, be deemed an employee of the municipality, notwithstanding the vehicle was being operated in the discharge of a public duty for the benefit of all citizens of the community and the municipality derived no special benefit in its corporate capacity. 26

Sec. 50-b. Municipal liability for negligent operation of vehicles or other facility of transportation. Every county, city, town, village and other subdivision of government, notwithstanding any inconsistent provisions of law, general, special or local or any limitation contained in the provision of any city charter, shall be liable and shall assume the liability for the negligence of, and shall save harmless, a person duly appointed by the governing board or body of the municipality, or by any board, body, commission or other officer thereof, in the operation of a municipally owned vehicle or other facility of transportation within the state in the discharge of a statutory duty imposed upon such person or municipality, pruvided the appointee at the time of the accident or injury was acting in the discharge of his duties and within the scope of his employment. Every such appointee shall, for the purpose of this section, be deemed an employee of the municipality, notwithstanding the vehicle or other facility of transportation was being operated in the discharge of a public duty for the benefit of all citizens of the community and the municipality derived no special benefit in its corporate capacity. 27

Sec. 50-c. Municipal liability for negligent operation of certain vehicles in the performance of duty by policemen and firemen. Every city, town and village, notwithstanding any inconsistent provision of law, general, special or local or the limitation contained in the provisions of any city charter, shall be liable for, and shall assume the liability to the extent that it shall save harmless any duly appointed policeman or fireman of the municipality for, the negligence of such appointee in the operation of a vehicle upon the public streets or highways of the municipality in the discharge of a statutory duty imposed upon such appointee or municipality, provided the appointee at the time of the accident, injury or damages complained of, was acting in the performance of his duties and within the scope of his cmployment. . . 28

Sec. 50-d. Municipal liability for malpractice of certain physicians and dentists in public institutions. Every municipal corporation, notwithstanding any inconsistent provision of law, general, special or local, shall be liable for, and shall assume the liability, to the extent that it shall save him harmless, of any physician or dentist rendering medical services or dental services of any kind gratuitously to a person in a public institution maintained in whole or in part by the municipal corporation, for damages for personal injuries alleged to have been sustained by such person by reason of the malpractice of such physician or dentist while engaged in the rendition of such services. Every such physician or dentist, for the purpose of this section, shall be deemed an employee of the municipal corporation, so maintaining such institution, notwithstanding that the municipal corporation derived no special benefit in its corporate capacity.

No-action shall be maincained under this section against such municipal corporation, physician or dentist unless the applicable provisions of law pertaining to the commencement of action and the filing of notice of intention to commence action against such municipal corporation shall be strictly complicd with.29

Sec. 7r. Liability for damages by mobs and riots. A city or county shall be liable to a person whose property is destroyed or injured therein by a mob or riot, for the damages sustained thereby, if the consent or negligence of such person did not contribute to such destruction or injury, and such person shall have used all reasonable diligence to prevent such damage, shall have notified the mayor of the city, or sheriff of the county, of a threat or attempt to destroy or injure his property by a mob or riot, immediately upon

${ }^{20}$ Laws 1940, c. 687, of April 22, 1940. This law superseded Laws 1936, c. 100, of March 14, 1936, which was similar except that it imposed liability only where the vehicle was operated "upon the public streets and highways of the municipality."

${ }^{27}$ Laws 1941, c. 852, of April 28, r94r. This law superseded Laws 1936, c. 323, of April 9, 1936, which was similar except that it imposed liability only where the vehicle was operated "upon the public streets and highways of the municipality."

${ }^{28}$ Laws 1936, c. 323, of April 9, 1936.

${ }^{29}$ Laws $x 937$, c. 483 , of May 22, x937. 
acquiring such knowledge, and shall bring an action therefor within three months after such damages were sustained. A mayor or sheriff receiving notification of a threat or attempt to destroy or injure property by a mob or riot shall take all lawful means to protect such property; and if he shall neglect or refuse, the person whose property shall be destroyed or injured, may elect to bring his action for damages against such officer instead of the city or county. 30

Sec. 205-b. Relief of volunteer firemen engaged in the performance of duty as such firemen from civil liability and liability of fire districts for the acts of volunteer firemen. Members of duly organized volunteer fire companies in this state shall not be liable civilly for any act or acts done by them in the performance of their duty as volunteer firemen, except for wilful negligence or malfeasance. Nothing in this section contained shall in any manner affect the liability imposed upon cities, towns and villages by section two hundred and eighty-two-g of the highway law, but fire districts created pursuant to law shall be liable for the negligence of volunteer firemen duly appointed to serve therein in the operation of vehicles owned by the fire district upon the public streets and highways of the fire district, provided such volunteer firemen, at the time of any accident or injury, were acting in the discharge of their duties. Judgments recovered against a fire district pursuant to this section shall be levied upon the taxable property of such district in the same manner as moneys raised for the support of the district.31

\section{NEW YORK HIGHWAY LAW}

Sec. 58. Liability of state for damages. The state shall not be liable for damages suffered by any person from defects in state highways, except between the first day of May and the fifteenth day of November on such highways as are maintained by the state under such system as the superintendent of public works may adopt pursuant to section twelve, but the liability for such damages shall otherwise remain as now provided by law, notwithstanding the construction or improvement and maintenance of such highways by the state under this chapter; but nothing herein contained shall be construed to impose on the state any liability for defects in bridges over which the state has no control. Within the limits of incorporated villages the state shall maintain a width of pavement equal to the width of pavement constructed or improved at the expense of the state, if a state highway, the location of the state's portion of such roadway within said incorporated limits to be determined by the center line of the roadway as shown on the plans on file with the department of public works and the state shall be liable for damages to persons or property only when such damage shall occur as a result of the defective condition of the portion of improved highway as above described.32

Sce. 197. Damages for change of grade. In any town in which a town highway shall be repaired, graded and macadamized from curb to curb by the authorities of the town the owner or owners of the land adjacent to the said highway shall be entitled to recover from the town the damages resulting from any change of grade. . . .33

Scc. 215. Liability of towns in certain actions.

I. No civil action shall be maintained against any town for damages or injuries to person or property sustained by reason of any highway, bridge or culvert being defective, out of repair, unsafe, dangerous or obstructed unless written notice of such defective, unsafe, dangerous or obstructed condition of such highway, bridge or culvert was actually given to the town clerk or town superintendent of highways, and that there was a failure or neglect within a reasonable time after the giving of such notice to repair or remove the defect, danger or obstruction complained of, or, in the absence of such notice, unless such defective, unsafe, dangerous or obstructed condition existed for so long a period that the same should have been discovered and remedied in the exercise of reasonable care and diligence; but no such action shall be maintained for damages or injuries to person or property sustained solely in consequence of the existence of snow or ice upon any highway, bridge or culvert, unless written notice thereof, specifying the particular place, was actually given to the town clerk or town superintendent of highways and there was a failure or neglect to cause such snow or ice to be removed, or to make the place otherwise reasonably safe within a reasonable time after the receipt of such notice.

2. No civil action shall be maintained against any town for damages or injuries to person or property sustained by reason of any defect in its sidewalks or in consequence of the existence of snow or ice upon any of its sidewalks, unless such sidewalks have been constructed or are maintained by the town or the superintendent of highways of the town pursuant to statute, nor shall any action be maintained for damages or injuries to person or property sustained by reason of such defect or in consequence of such existence of snow or ice unless written notice thereof, specifying the particular place, was actually given to the town clerk or to the town superintendent of highways, and there was a failure or neglect to cause such defect to be remedied, such snow or ice to be removed, or to make the place otherwise reasonably safe within a reasonable time after the receipt of such notice.

${ }^{30}$ Consoz. Laws of N. Y. (Cahill, $2 d$ ed. 1930), c. $26, \$ 71$.

${ }^{31}$ Laws $x 936$, c. 384 , of May 2, 1936. ${ }^{32}$ Id. c. 63, of March 4, 1936. ${ }^{33}$ Ibid. 
3. No action shall be maintained against any town to recover any such damages, unless a notice of claims shall have been filed with the town clerk and supervisor of the town within ninety days after the cause of action accrued. Such notice shall contain a statement of the place of residence of the complainant, a description of the time when and the particular place where and the circumstances under which the injuries complained of were sustained, the cause thereof, and, so far as then practicablc, the nature and extent thereof, and shall be verified by the complainant; and the town shall not be liable unless such verified notice is so filed. No action shall be commenced upon such claim until the expiration of fifteen days after the service of such notice and no action may be commenced subsequent to one year after the alleged cause of action accrued.34

Sec. 2x6. When town not liable for damages. No town shall be liable for any damage resulting to persons or property by the reason of the breaking of any bridge, sluice or culvert, by transportation on the same of any traction engine, portable piece of machinery, or of any vehicle or load, together weighing eight tons or over, but any owner thercof or other persons engaged in transporting or directing the same shall be liable for all damages resulting therefrom.35

The following section $282-\mathrm{g}$ was added to Highway Law by Laws 1929, c. 466, and would have been part of Article II, which Article, however, had been repealed earlier by Vehicle and Traffic Law enacted in L. 1929, c. 54. Because section $282-\mathrm{g}$ was apparently intended to be part of the Vehicle and Traffic Law, it is set forth with section 59 of the Vehicle and Traffic Law (Negligence of operator other than owner attributable to owner).

Sec. 282-g. Municipal liability for negligent operation of vehicles. Every city, town and village shall be liable for the negligence of a person duly appointed by the governing board or body of the municipality, or by any board, body, commission or other officer thereof, to operate a municipally owned vehicle upon the public streets and highways of the municipality in the discharge of a statutory duty imposed upon the municipality, provided the appointee at the time of the accident or injury was acting in the discharge of his duties and within the scope of his employment. Every such appointec shall, for the purpose of this section, be deemed an employee of the municipality, notwithstanding the vehicle was being operated in the discharge of a public duty for the benefit of all citizens of the community and the municipality derived no special benefit in its corporate capacity. 36

\section{NEW YORK JUDICIARY LAW}

Sec. x20. Official referees of the court of claims. The justices of the appellate division of the supreme court in the respective four judicial departments may from time to time appoint as an official referee of the court of claims any person residing within such department who shall have retired or shall hereafter retire from the office of judge of such court having served as a judge or justice of a court or courts of record for a total period of twenty years or any judge of such court who shall not have served for such period but whose term of office as a judge of such court shall expire by reason of his having attained the constitutional age limit.

Such official referee of the court of claims shall hear and determine or hear and rcport upon any claim against the state referred to him by the court of claims, upon the consent of the attorney-general and the claimant. He shall receive no compensation from the parties for his services as such referec. Such a referee also shall render such temporary assistance to the court of claims as he shall be designated to perform by the presiding judge thereof, whenever such court requires such assistance because of the illness of a judge or his disqualification to hear a particular matter, and also whenever there is such an accumulation of work before the court as to render such assistance necessary in order to enable it promptly to dispose of the business before it. When so assisting such court, under designation from the presiding judge, such referee shall be deemed an acting judge of the court and shall have the powers and jurisdiction of a judge of such court.37

\section{NEW YORK MENTAL HYGIENE LAW}

Sec. 44. Actions against the commissioner of mental hygiene, visitors or officers of state institutions. No civil action shall be brought in any court against the commissioner or an assistant commissioner of mental hygiene, or an officer or employee or a visitor of a state institution in the department, in his personal capacity, for alleged damages because of any act done or failure to perform any act, while discharging his official duties, without leave of a judge of the supreme court, first had and obtained. Any such officer or employee in any such action shall not be liable for damages if he shall have acted in good faith, with reasonable care and upon probable cause.

Any just claim for damages against such commissioner, officer, visitor, or employce for which the state would be legally or equitably liable, shall be brought and maintained in the court of claims as a claim against the state. 38

"Laws 1941, c. 677, of April 22, 1941. This section repeals the former $\$ 215$.

${ }^{85}$ Laws r936, c. 63, of March 4, 1936. $\quad{ }^{30}$ Laws 1929, c. 466, of April 10, 1929.

${ }^{87}$ Laws $\mathrm{x} 935$, c. 854 , of July I, I935.

${ }^{38}$ Laws $\times 935$, c. 478, of April 25, 1935. 


\section{NEW YORK PUBLIC AUTHORITIES LAW}

Sec. 645-a. Actions against the authority.

1. In every action against the authority for damages, for injuries to real or personal property, or for the destruction thereof, or for personal injuries or death, the complaint shall contain an allegation that at least thirty days have elapsed since the demand, claim or claims upon which such action is founded were presented to a member of the authority, or to its secretary, or to its chief executive officer and that the authority has neglected or refused to make an adjustment or payment thereof for thirty days after such presentment.

2. An action against the authority for damages for injuries to real or personal property, or for the destruction thereof, or for personal injuries or death, alleged to have been sustained, shall not be commenced more than one year after the cause of action therefor shall have accrued, nor unless a notice of intention to commence such action and of the time when and place where the damages or personal injuries or death were incurred or sustained, together with a verified statement showing in detail the property alleged to have been damaged or destroyed and the value thereof, or the personal injuries alleged to have been sustained and by whom, shall have been filed with the secretary of the authority in the principal office of the authority within six months after such cause of action shall have accrued.39

\section{NEW YORK PUBLIC HOUSING LAW}

Sec. 15. Actions and proceedings against the commissioner or the state; the commissioner as a necessary party defendant. With regard to duties or liabilities arising out of this chapter, the state or the commissioner may be sued in the same manner as a private person. In any action or proceeding affecting any state project or the project of a housing company the commissioner, in addition to all other necessary parties, shall be made a party defendant and he shall take such steps in such action or proceeding as may be necessary to protect the public interest. Whenever in connection with a state project under any instrument or law, a notice of default in writing is required to be served upon an authority or municipality before the institution of any action or proceeding, a copy of such notice shall be served upon the commissioner at least five days before commencement of the action or proceeding. No costs shall be awarded against the commissioner or the state in any such litigation.40

\section{NEW YORK SECOND CLASS CITIES LAW}

Sec. 244. Liability of city in certain actions. No civil action shall be maintained against the city for damages or injuries to person or property sustained in consequence of any street, highway, bridge, culvert, sidewalk or crosswalk being defective, out of repair, unsafe, dangerous or obstructed unless it appear that written notice of the defective, unsafe, dangerous, obstructed condition . . . was actually given to the commissioner of public works, and that there was a failure or neglect within a reasonable time after the giving of such notice to repair, or remove the defect, danger or obstruction complained of, or, in the absence of such notice, unless it appears that such . . . condition existed for so long a period that the same should have been discovered and remedied in the exercise of reasonable care and diligence. But no such action shall be maintained for damages or injuries to the person sustained solely in consequence of the existence of snow or ice upon any sidewalk, crosswalk or street, unless written notice thereof . . . was actually given to the commissioner of public works and there was a failure or neglect to cause such snow or ice to be removed, or the place otherwise made reasonably safe within a reasonable time after the receipt of such notice. The city shall not be liable in a civil action for damages or injuries to person or property, or invasion of personal or property rights, of any name or nature whatsoever . . . unless a claim therefor in writing ... shall within three months after the happening of the accident or injury ... be presented to the common council and served upon the mayor or city clerk and notice of intention to commence an action thereon be served upon the corporation counsel, nor unless an action shall be commenced thereon within one year after the happening of such accident or injury or the occurrence of such act, omission, fault or neglect; but no action shall be commenced to recover upon or enforce any such claim against the city until the expiration of three months after the service of said notice upon the corporation counsel. ...41

\section{NEW YORK TOWN LAW}

Sec. 67. Presentation of claims for injury to person or property. Any claim other than a claim specified in section two hundred and fifteen of the highway law which may be made against the town for damages for wrong or injury to person or property or for the death of a person, shall state when, where and how such injuries or death were occasioned and the nature and extent of such injuries and duplicate copies thereof shall be filed with the supervisor and town clerk of the town. Such notice shall be filed within ninety days after the injury complained of and shall contain a statement of the place of residence

\footnotetext{
${ }^{30}$ Laws 1940, c. 499, of April 15, 1940.

${ }^{50}$ Laws 1940, c. I48, of March 12, x940.
}

${ }^{11}$ Laws 1940 , c. 406, of April II, 1940, apparently replacing the old Section 244. 
of the complainant, a description of the time when and the particular place where and the circumstances under which the injuries complained of were sustained, the cause thercof, and, so far as then practicable, the nature and extent thereof and shall be verified by the complainant, and the town shall not be liable unless such verified notice or a copy thereof be so filed. No action shall be commenced upon such claim until the expiration of fifteen days after the service of such notice and no action may be commenced subsequent to one year after the alleged cause of action accrued. This section shall not apply to claims for damages or compensation for property taken for highway purposes. . . 42

\section{NEW YORK VILLAGE LAW}

Sec. 341. Actions against the village. No action shall be maintained against the village for damages for a personal injury or an injury to property alleged to have been sustained by reason of the negligence of the village or of any officer, agent or employee thereof, unless the same shall be commenced within one year after the cause of action therefor shall have accrued nor unless a written verified statement of the nature of the claim and of the time and place at which such injury is alleged to have been reccived, or a copy of such statement, shall have been filed with the village clerk within thirty days after the cause of action shall have accrued. An action on such a claim shall not be commenced until the cxpiration of thirty days after it is presented.43

Sec. 341a. Liability of village in certain actions. No civil action shall be maintained against the village for damages or injuries to person or property sustained in consequence to any strect, highway, bridge, culvert, sidewalk or crosswalk being defective, out of repair, unsafe, dangerous or obstructed unless it appear that written notice of the . . . condition . . . was actually given to the board of trustces, and that there was a failure or neglect within a reasonable time after the giving of such notice to repair, or remove the defect .... or, in the absence of such notice, unless it appears that such defective . . . condition existed for so long a period that the same should have been discovered and remedicd in the exercise of reasonable care and diligence. But no such action shall be maintained for damages or injuries to the person sustained solely in consequence of the existence of snow or ice upon any sidewalk, crosswalk or street, unless written notice thereof, relating to the particular place, was actually given to the board of trustees and there was a failure or neglect to cause such snow or ice to be removed, or the place otherwise made reasonably safe within a reasonable time after the receipt of such notice.44

Sec. 34r-b. Liability of villages in certain actions. Except as provided in sections one hundred and fifty-nine, three hundred and forty-one and three hundred and forty-one-a of this chapter, no action shall be maintained against the village upon or arising out of a contract of the village unless the same shall be commenced within eighteen months after the cause of action therefor shall have accrued, nor unless a written verified claim shall have been filed with the village clerk within one year after the cause of action shall have accrued, and no other action shall be maintained against the village unless the same shall be commenced within one year after the cause of action therefor shall have accrued, nor unless a written verified claim, stating the time when and the place where such claim arose and in detail the nature of the same, and of the items of damage alleged or claimed to have been sustained, together with a written notice of intention to sue the village shall have been filed with the village clerk within six months after the cause of action shall have accrued. The omission to present a claim or to commence an action thercon within the respective periods of time above stated applicable to such claim, shall be a bar to any claim or action therefor against said village; but no action shall be brought upon any such claim until forty days have clapsed after the filing of the claim in the office of the village clerk.45

\section{The Small Town}

It has been suggested above that the small town may by its representations in the state legislature vote against any statute which would impose community liability in tort, since a single widespread accident might lay an unbearable burden on the town. This consideration does not seem to have deterred New York from imposing tort liability on towns and villages for certain types of public injury. But in other states questions and doubts have been raised, so that for such cases a solution may be suggested. Such towns might be persuaded to make some contribution from their tax revenues to a state fund, provided their liability were limited. Thus, communities having a gross revenue from taxation less than $\$ 250,000$ per year-i.e., communities

\footnotetext{
42 Laws x941, c. 30, of Feb. 26, 1941, replacing Laws 1935, c. 435, of April 23, 1935.

s Laws 1940, c. 405, of April II, 1940, apparently replacing Laws 1927, c. 650, of July I, 1927.

"Laws 1927, c. 650, of July $x$, 1927 .

"Laws 1937, c. 745 , of May $28,1937$.
} 
possibly of less than ro,000 inhabitants-might pay into a state fund $2 \%$ of their tax revenues in lieu of their liability under the Act. The state should assume any excess of liability beyond this amount. This may be justified on the ground that many local functions are now characterized by the courts as really state functions, carrying immunity under the existing law. In addition, the local community is often obliged to take care of streets and highways-the source of many tort claims-whereas the use is statewide. It seems fair that the state should assume a share of the liability, a fact which might induce the state to assume a greater share of the expense of maintenance and repair, thus preventing or reducing accidents. The burden of maintenance is often too great for a small community to bear, and a more equitable distribution of the burden seems sound policy. Better statutory definition of the duty of maintenance in streets and highways would also help efficient administration of the liability statute. As an incentive to efficient government, a local community which does not exhaust its 2 per cent liability contribution in any one year might be given credit for the unexpended portion in the next year, and returns might be made of excess amounts paid in, say every five years. Insurance of the liability is no permanent solution, for premiums will tend to adjust themselves to the risk assumed and the practice might be conducive to inefficient administration.

The question then arises how proceedings against smaller communities shall be administered. Shall their local councils or executive boards be permitted to adjust such claims when the payment is to be made by the state? They might have less interest in holding the claim down if that were done. The suggestion in the section below looks to the filing of a claim against the local unit with that unit, but for a review by the State Administrative Board of any settlement and allowance, and provides that all suits arising out of the claim shall be brought jointly against the state and the local subdivision. This suggestion is admittedly very debatable.

It has been suggested that to avoid the cumbersome necessity for claimants of trifling amounts having to submit their claims to the state capitol, with reports from local officers to the State Board of Administration and possibly a visit by a state official to investigate an unimportant local accident, the smaller local units might themselves be willing to assume, under rules from the State Board, liability for injuries in which the claim amounts to less than \$100. Inasmuch as most claims would probably be for small amounts, decentralization to this extent might prove helpful in administration, would assure local subdivisions against unknown or excessive liability, and would also guarantee the sense of local responsibility which a complete immunity from local liability might sacrifice. State rules would simplify the procedure and make it uniform. Promptness of adjudication for small claims would also be assured. While it may be impossible to predict the number of tort claims, the risk could hardly be great, for the liability is limited. This provision for local assumption of limited liability independently of the contribution to the state fund is not included in the appended draft, but it might be given consideration. It may be added that a research body in each state ought closely to observe the ad- 
ministration of the Act, to determine by experience the necessary amendments and modifications.

The statute on this question might read:

Section $[x L]$. In the case of a county, city, municipal corporation, school district, district established by law, or other political subdivision [i.e., municipal corporation], having a gross revenue from taxation from all sources of less than $\$ 250,000$ per annum, the said county, city, municipal corporation, school district, district established by law, or other political subdivision [i.e., municipal corporation] shall contribute to the general fund of the state an amount per annum not less than two per cent of its gross revenue from taxation from all sources, in lieu of direct liability for private claims established by this Act; but in that event, the settlement, adjustment, and allowance of claims against the said subdivision shall be reviewed and may be revised by the State Administrative Board, and all suits arising out of the claim shall be brought against the state jointly with the county, city, municipal corporation, school district, district established by law, or other political subdivision [i.e., municipal corporation] primarily liable.

We have thus presented some of the principal considerations which arise in the process of translating into legislation the assumption of liability by the community for the torts or misfeasance of public officers and employees. Since the principle is now admitted in the federal government and in many states and cities of this country, it may be hoped that the practical administration of the liability, with justice to the victim, the community and the officer, will not be too difficult to accomplish. 